\title{
Description of two new species of Rhynchelmis (Oligochaeta: Lumbriculidae) from Lake Baikal (Russia), using classical morphology and ultrastructure of spermatozoa
}

\author{
P. Martin 1 \\ M. Ferraguti ${ }^{2}$ \\ I. Kaygorodova ${ }^{3}$
}

Keywords : aquatic oligochaetes, Lumbriculidae, Rhynchelmis, taxonomy, Baikal.

The study of new samples of oligochaetes from Lake Baikal (Siberia) made possible description of two new species of the genus Rhynchelmis, $R$. alyonae $\mathrm{sp} . \mathrm{n}$. and $R$. shamanensis $\mathrm{sp}$. $\mathrm{n}$. Rhynchelmis alyonae $\mathrm{sp}$. $\mathrm{n}$. has modified genital setae, a character mentioned for the third time in the Lumbriculidae. These species belong to a complex of small Rhynchelmis, characterised by two pairs of testes, two pairs functional sperm funnels, no connection between spermathecae and gut cavity, and short, elongate, straight atria extending, at most, into segment XII. Other representatives of this group are $R$. olchonensis, $R$. paraolchonensis and probably $R$. spermatochaeta. The Hrabe specimens of $R$. olchonensis are not considered to belong to this species and are included into $R$. shamanensis $\mathrm{sp}$. $\mathrm{n}$. An examination of the ultrastructure of spermatozoa of $R$. alyonae $\mathrm{sp} . \mathrm{n}$. indirectly gives some support to the validity of this group. The group is suspected to harbour other new species in Lake Baikal where it seems more and more to constitute a species flock.

Description de deux nouvelles espèces de Rhynchelmis (Oligochaeta, Lumbriculidae) du lac Baikal (Russie), à partir de caractères morphologiques classiques et de l'ultrastructure des spermatozoïdes.

Mots clés : oligochètes aquatiques, Lumbriculidae, Rhynchelmis, taxinomie, Baïkal.

L'étude de nouveaux échantillons d'oligochètes en provenance du lac Baíkal (Sibérie)-a permis de décrire deux nouvelles espèces du genre Rhynchelmis, $R$. alyonae $\mathrm{n}$. sp. et $R$. shamanensis $\mathrm{n}$. sp. Rhynchelmis alyonae $\mathrm{n}$. $\mathrm{sp}$. a des soies génitales modifiées, un caractère signalé pour la troisième fois chez les Lumbriculidae. Ces espèces appartiennent à un complexe de Rhynchelmis de petite taille, caractérisé par deux paires de testicules, deux paires de pavillons spermatiques, l'absence de communication entre les spermathèques et la cavité intestinale, et des atria de petite taille, allongés et droits, s'étendant jusqu'au segment XII, au plus. D'autres représentants de ce groupe sont $R$. olchonensis, $R$. paraolchonensis et probablement $R$. spermatochaeta. Les spécimens de Hrabè de $R$. olchonensis ne sont plus considérés comme appartenant à cette espèce mais sont incorporés dans $R$. shamanensis $\mathrm{n}$. sp. Un examen de l'ultrastructure des spermatozoïdes de $R$. alyonae $\mathrm{n}$. sp. supporte indirectement la validité de ce groupe. Ce dernier est suspecté d'abriter d'autres nouvelles espèces dans le lac Baikal, où il semble, de plus en plus, constituer un «species flock».

\section{Introduction}

The Lumbriculidae are one of the most important families in Lake Baikal. About one third of the whole world's known lumbriculid taxa indeed inhabits the la-

1. Institut royal des Sciences naturelles de Belgique (IRScNB), Section Biologie des Eaux douces, 29 rue Vautier, B-1000 Bruxelles, Belgium.

2. Dipartimento di Biologia, Université di Milano, Via Celoria 26, I-20133, Milano, Italy.

3. Limnological Institute, Siberian Branch of the Academy of Sciences of Russia, Ulan-Batorskaya 3, 664033 Irkutsk, Russia. ke. Fourty-six species have been recently reported from Lake Baikal, 40 of which are endemic (Snimschikova \& Akinshina 1994, Martin 1996).

In Lake Baikal, the family underwent an intensive evolutive radiation, giving rise to a variety of forms, including dwarf and giant species (as Lamprodrilus pygmaeus Michaelsen, 1902 and Rhynchelmis brachycephala Michaelsen, 1901, respectively), and even species flocks (amongst the 26 Lamprodrilus species known so far, 19 are indeed endemic to the lake).

Amongst the Lumbriculidae, the genus Rhynchelmis Hoffmeister, 1843 is one of the less represented in La- 
ke Baikal. Only four species have been described so far, namely $R$. brachycephala, $R$. olchonensis Burov and Kozhov, 1932, R. spermatochaeta Semernoy, 1982 , and $R$. tetratheca Michaelsen, 1920, the first three being endemic. This is fairly surprising in an ancient lake known for holding the highest biodiversity of all extant lakes (Martin 1994). Only Agriodrilus Michaelsen, 1905 and Lumbriculus Grube, 1884 have one representative in Lake Baikal but the former, remarkable for its predatory habits, is an endemic genus while the latter is not found in the open lake.

A recent examination of Semernoy's private oligochaete collection (University of Yaroslavl, Russia) suggested the existence of a more complex group of Rhynchelmis species in Lake Baikal than previously assumed. The study of new samples of oligochaetes from the lake gave more support to this presumption by revealing two new species of the genus Rhynchelmis.

\section{Material and methods}

The material was sampled in Olkhonskiye varota (Olchon's gate) in 1996, during the June expedition of the $R / V$ Vereschagin of the Limnological Institute of Irkutsk. This «varota» provides a passage between the lake and the Maloye More (Small Sea), a channel delimited on the left side by the lake shore, on the right side by Olkhon Island, and is more or less isolated from the influence of the open lake (Kozhov 1963, Martin 1994). Samples were taken by means of a small dredge operating between 30 and $14 \mathrm{~m}$ depth.

Specimens destined to sperm ultrastructure study were fixe on board the ship in a cacodylate bufferedglurtaraldehyde-paraformaldehyde mixture in picric acid. Thegenital segments were cut to facilitate the penetration of the fixative. The animals were washed overnight in $0.1 \mathrm{M}$ cacodylate buffer, postfixed in similarily buffered $1 \%$ osmium tetroxide, pre-stained in aqueous uranile acetate, dehydrated in a grade ethanol series, and embedded in Spurr's resin. The sections, obtained with an LKB Ultrotome V, were stained in lead citrate, carbon coated, and observed under a Jeol $100 \mathrm{XS}$ electron microscope.

All other samples were preserved in $80 \%$ ethanol for another study on molecular phylogeny of Oligochaeta of the lake. Specimens used for classical morphological work were later fixed overnight in the laboratory with $7 \%$ neutralised formalin before being dissected. Worms were stained with alcoholic carmine and mounted in Canada balsam. Drawings were made by means of a camera lucida. The type series are depo- sited in the Royal Belgian Institute of Natural Sciences (IRSNB; Brussels) and the Limnological Institute of Irkutsk (LISB).

\section{Rhynchelmis alyonae sp. $\mathrm{n}$.}

\section{Holotype.}

IRSNB, I.G. 28235, slide 97.024.1, mature specimen, incomplete (first 60 segments), dissected, stained in alcohol carmine and mounted in Canada balsam.

Type locality.

Lake Baikal, Maloye More, Olkhonskiye varota, $\mathrm{Ca}$ -

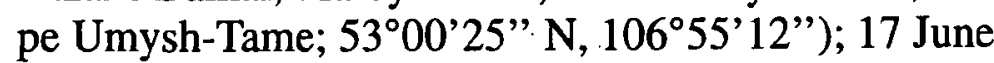
1996; at 14-30 m depth (dredge); silty sandy sediment.

\section{Paratypes.}

9 sexually mature specimens from the same station, dissected and mounted in the same way as the holotype; IRSNB slides 96.190.01, 97.028.1, 97.042.2, 97.071.2; LISB slides 71.4, 71.6, 71.9, 71.17; 1 sexually mature specimen in alcohol (IRSNB).

\section{Etymology.}

The species is dedicated to Alyona, the daughter of one of us (IK), who took part in the '96 expedition on Lake Baikal and whose loveliness and childhood freshness symbolize the magnificence of the lake.

\section{Description.}

Medium-sized species, $24 \mathrm{~mm}, 107$ segments, breadth $465-612 \mu \mathrm{m}$ at widest (clitellum). Prostomium rounded. Inconspicuous secondary annulation from III to VII, narrow annulus posterior, intersegmental annulation well-marked in postclitellar segments. Clitellum slightly noticeable, extending over $1 / 2$ IX 1/2 XIII. Two single-pointed setae per bundle, sigmoid, with bent tips, similar in dorsal and ventral bundles, 96 - $136 \mu \mathrm{m}$ long, $5.0-5.6 \mu \mathrm{m}$ thick, ectal nodulus on the upper third of seta (Fig. 1C). Two modified penial setae per bundle in X, 163-167 $\mu \mathrm{m}$ long, 5.6 $\mu \mathrm{m}$ thick, elongate, straight, cane-like curved entally, ental nodulus on the lower quarter of seta (Fig. 1D, gs). Setal length increasing from $96 \mu \mathrm{m}$ to $125-136 \mu \mathrm{m}$ in V-IX, slightly decreasing to a nearly constant length (115 - $125 \mu \mathrm{m})$ in postclitellar segments.

Dorsal pad of pharynx extending from II to IV, pharyngeal glands in II-VII. Two pairs of sperm sacs associated with each testis segment, backward pouchings of septa $9 / 10$ and $10 / 11$, confined in X-XI or extending to XVII, respectively (Fig. 1A, asps, psps). Egg sacs reaching XXII. One pair of spermathecal pores opening in the middle of VIII, on the same line as ventral 
setae. Spermathecal pores modified into well-developed papillae (Fig. 1B, spp), giving rise to short bulbi (Fig. 1B, spb), constituted by a thickening of epithelial cells without significant strengthening of muscles of the body-wall; thickening of tegument extending towards VIII/IX intersegmental furrow. Long and tubular spermathecal ducts (Fig. 1B, spd), leading to voluminous ampullae (Fig. 1B, spa) roughly divided into two pouches of different sizes, a small proximal and a large distal one. One ampulla usually filling the coelom in VIII, the other partially or totally pushed backwards in IX. Sperm as an amorphous mass in ampullae. No communication between spermathecal ampullae and gut cavity.

Two pairs of testes in IX and X, attached ventrally to septa $8 / 9$ and 9/10, respectively (Fig. 1A,B, $t$ ). Male pores paired, in line with setae, opening ventrally slightly before intersegmental furrow X/XI (Fig. 1A, $m p$ ). Two pairs of sperm funnels on septa $9 / 10$ and 10/11, respectively (Fig. 1A, $s f$ ), posterior ones taller than anterior ones and directed towards posterior sperm sac. Two pairs of vasa deferentia (Fig. 1A, vd). Anterior vas deferens running on the floor of $X$, posterior vas deferens making some loops in XI before turning back to $X$, both running along atrium proximal to this, besides its muscle coat, and penetrating atrium subapically. Vasa deferentia $29 \mu \mathrm{m}$ wide, narrower when associated with atria ( $14 \mu \mathrm{m}$ wide). Cylindrical, elongate atria, $932 \mu \mathrm{m}$ long, $81 \mu \mathrm{m}$ wide, entering sperm sacs and extending to XII, inclusively (Fig. 1A, a). Proximal part of atria pedunculated, terminated by small penes (Fig. 1A, $p$ ) in penial sacs. Different type of cells in peduncle, apparently not glandulary. No rudimentary atrium. Prostate glands discrete, covering atria, constituded by large cells, grouped together in elongate or pear-shaped masses, separately opening onto atrium by means of short duct (Fig. 1A, pr). One pair of massive accessory copulatory glands (Fig. $1 \mathrm{~A}, \mathrm{D}, c g l)$, surrounding penial setae and opening ventrally by small pores surrounded by tall epithelial cells, in line with male pores, in the anterior third of segment $\mathrm{X}$.

Female pores paired, in line with setae and spermathecal, glandular and male pores. Female funnels tall, ciliated, attached to septum $11 / 12$, opening onto intersegmental furrow XI/XII (Fig. 1A, ff). Ovaries paired, fixed ventrally near septum $10 / 11$ and extending to XII-XIII (Fig. 1A, ov).

\section{Ultrastructure of spermatozoa.}

Long, filiform spermatozoon with a nearly constant diameter, made by a sequence of acrosome, nucleus, mitochondrial midpiece, and tail (Fig. 3). Acrosome
$1 \mu \mathrm{m}$ long, highly complex (Fig. 2C,D; Fig. 3, ac), twisted-shaped with an acrosome tube involving other acrosomal components, i.e. acrosome vesicle, acrosome rod and secondary tube. Acrosome tube with a basal portion clearly differentiated from the apical one, more faint. Acrosome vesicle occupying the anterior two thirds of acrosome, and containing some dense material. Basal portion of acrosome vesicle invaginated for a long tract to host part of acrosome rod (Fig. 2C,D; Fig. 3, ar), the latter terminating basally at proximal end of tube. Faint secondary tube (connection to basal extremity of acrosome vesicle not obvious) surrounding rod (Fig. 2D; Fig. 3, st, ar). Nucleus less than $30 \mu \mathrm{m}$ long, twisted-column shaped for its whole length (Fig. 2A) with an apical roughly conical concavity (Fig. 2D). Nucleus terminating basally towards mitochondria (Fig. 2B). Six mitochondria in $1.6 \mu \mathrm{m}$ long midpiece, cylindrical sector-like, highly twisted around main axis, with an obvious small canal (Fig. 2E). No conventional basal body but thick basal cylinder penetrating center of basal body (Fig. 2B,F). $9+2$ flagellum following with central tubules, characteristically «embedded» in a cylinder with considerable electron density (Fig. 2F)

\section{Remarks.}

The spermatozoa of Rhynchelmis alyonae sp. n. possess typical characters of Euclitellata (acrosome tube, mitochondria interposed between nucleus and tail, and modified central apparatus of axoneme); Oligochaeta (basal cylinder penetrating inside the basal body region) and Lumbriculidae (six highly twisted mitochondria, some dense material in acrosome) (Ferraguti $1984,1998)$. Besides these typical features, the conical cavity on top of the nucleus is a character found only in lumbriculids (Rhynchelmis sp., Kincaidiana Altman, 1936 sp.) and most Branchiobdellida, and is considered as a synapomorphy in these two groups (Ferraguti et al. 1998).

By comparison with Rhynchelmis brachycephala and Rhynchelmis limosella Hoffmeister, 1843, spermatozoa of $R$. alyonae sp. $\mathrm{n}$. show striking differences in the dimensions of their various parts, as well as in the shape of the nucleus, supporting a closer relationship between the former two than between $R$. brachycepha$l a$ and $R$. alyonae sp. n. (Ferraguti et al. 1998).

Genitalia of $R$. alyonae sp. n. are sometimes difficult to decipher, all the more so since atria enter sperm sacs and are surrounded by sperm material undergoing development. The exact junction of vas deferens with atrium was obscure on the holotype, and was suggested by a dashed line, but was clearly noticeable on paratype 97.071 .2 . 


\section{Abbreviations used in figures}

$\begin{array}{llllll}\text { a } & \text { atrium } & \text { atrium } & \text { np } & \text { nuclear pad } & \text { coussinet nucléaire } \\ \text { ac } & \text { acrosome } & \text { acrosome } & \text { ov } & \text { ovary } & \text { ovaire } \\ \text { ar } & \text { acrosome rod } & \text { tige acrosomiale } & \text { p } & \text { penis } & \text { pénis } \\ \text { asps } & \text { anterior sperm sac } & \text { sac spermatique antérieur } & \text { pr } & \text { prostate gland } & \text { glande prostatique } \\ \text { at } & \text { acrosome tube } & \text { tube acrosomial } & \text { psps } & \text { posterior sperm sac } & \text { sac spermatique postérieur } \\ \text { av } & \text { acrosome vesicle } & \text { vésicule acrosomiale } & \text { s } & \text { seta } & \text { soie } \\ \text { bc } & \text { basal cylinder } & \text { cylindre basal } & \text { sf } & \text { sperm funnel } & \text { pavillon spermatique } \\ \text { cgl } & \text { copulatory gland } & \text { glande copulatrice } & \text { sp } & \text { spermatozoa } & \text { spermatozoïdes } \\ \text { cf } & \text { ciliated funnel } & \text { pavillon cilié } & \text { spa } & \text { spermathecal ampulla } & \text { ampoule spermathécale } \\ \text { cr } & \text { cellular ring } & \text { anneau cellulaire } & \text { spb } & \text { spermathecal bulbus } & \text { bulbe spermathécal } \\ \text { ds } & \text { dorsal seta } & \text { soie dorsale } & \text { spd } & \text { spermathecal duct } & \text { canal spermathécal } \\ \text { ff } & \text { female funnel } & \text { pavillon femelle } & \text { spp } & \text { spermathecal papilla } & \text { papille spermathécale } \\ \text { gs } & \text { genital seta } & \text { soie génitale } & \text { spv } & \text { spermathecal vestibula } & \text { vestibule spermathécal } \\ \text { m } & \text { muscle } & \text { muscle } & \text { ss } & \text { setal sac } & \text { sac sétal } \\ \text { mdp } & \text { midpiece } & \text { pièce médiane } & \text { st } & \text { secondary tube } & \text { tube secondaire } \\ \text { mp } & \text { male pore } & \text { pore mâle } & \text { t. } & \text { testis } & \text { testicule } \\ \text { mt } & \text { mitochondria } & \text { mitochondrie } & \text { tl } & \text { tail } & \text { queue } \\ \text { n } & \text { nucleus } & \text { noyau } & \text { vs } & \text { ventral seta } & \text { soie ventrale }\end{array}$

The presence of one pair of spermathecae, opening on VIII, two segments in front of atrial segments (X), and of atria paired with thin muscular walls, defines our specimens unambiguously as Rhynchelmis. The lack of connection between ampullae of spermatheca and gut cavity, of a rudimentary atrium and of an inwards curling of longitudinal muscles at their margins places them close to Rhynchelmis olchonensis Burov \& Kozhov, 1932, Rhynchelmis paraolchonensis Giani \& Martinez-Ansemil, 1982, Rhynchelmis alaskana Holmquist, 1976 and Rhynchelmis orientalis Yamaguchi, 1936. Amongst them, only the first two share out the possession of two pairs testes and two pairs of functional vasa deferentia.

$R$. paraolchonensis has no copulatory glands and no genital setae in X, its atria are much shorter (286-380 $\mu \mathrm{m})$ and generally do not penetrate into XI, ventral setae from IV are very stout, with ectal tip bent at nearly a right angle (Fig. 5B), and spermathecal pores have no modified papilla and give rise to short vestibulae, by no means comparable to the ones of $R$. alyonae sp. $\mathrm{n}$.

$R$. olchonensis is probably the closest to $R$. alyonae sp. $\mathrm{n}$. It is similar in nearly all aspects but has no modified spermathecal pore, no genital setae in X and its atria do not extend behind segment XI. Genital setae should be so obvious to notice that we can confidently

rely on Burov and Kozhov's description. There are, however, no means to check this character ${ }^{1}$.

Originally, $R$. olchonensis was described with a large number of pear-shaped glandular cells surrounding ventral setae in X (Burov \& Kozhov 1932), as in $R$. alyonae $\mathrm{sp}$. $\mathrm{n}$. In his redescription of $R$. olchonensis, Hrabè (1982) was unable to see such a structure. A reexamination of his specimens confirmed this observation and led us to consider them as a new species (see below).

\section{Geographical distribution and habitat.}

To date, only known from Lake Baikal, Maloye More (Olkhonskiye varota, Cape Umysh-Tame, $30 \mathrm{~m}$, silty sand sediment).

\section{Rhynchelmis shamanensis Martin and Kaygorodova sp. $\mathbf{n}$.}

Pseudorhynchelmis olchonensis Burov \& Kozhov, 1932 sensu Hrabè, 1982: 190-191, figs 8-10, non Burov \& Kozhov, 1932.

\section{Holotype.}

IRSNB, I.G. 28235, slide 97.024.02, mature specimen, incomplete (first 26 segments), dissected, stained in alcohol carmine and mounted in Canada balsam. 
(5)
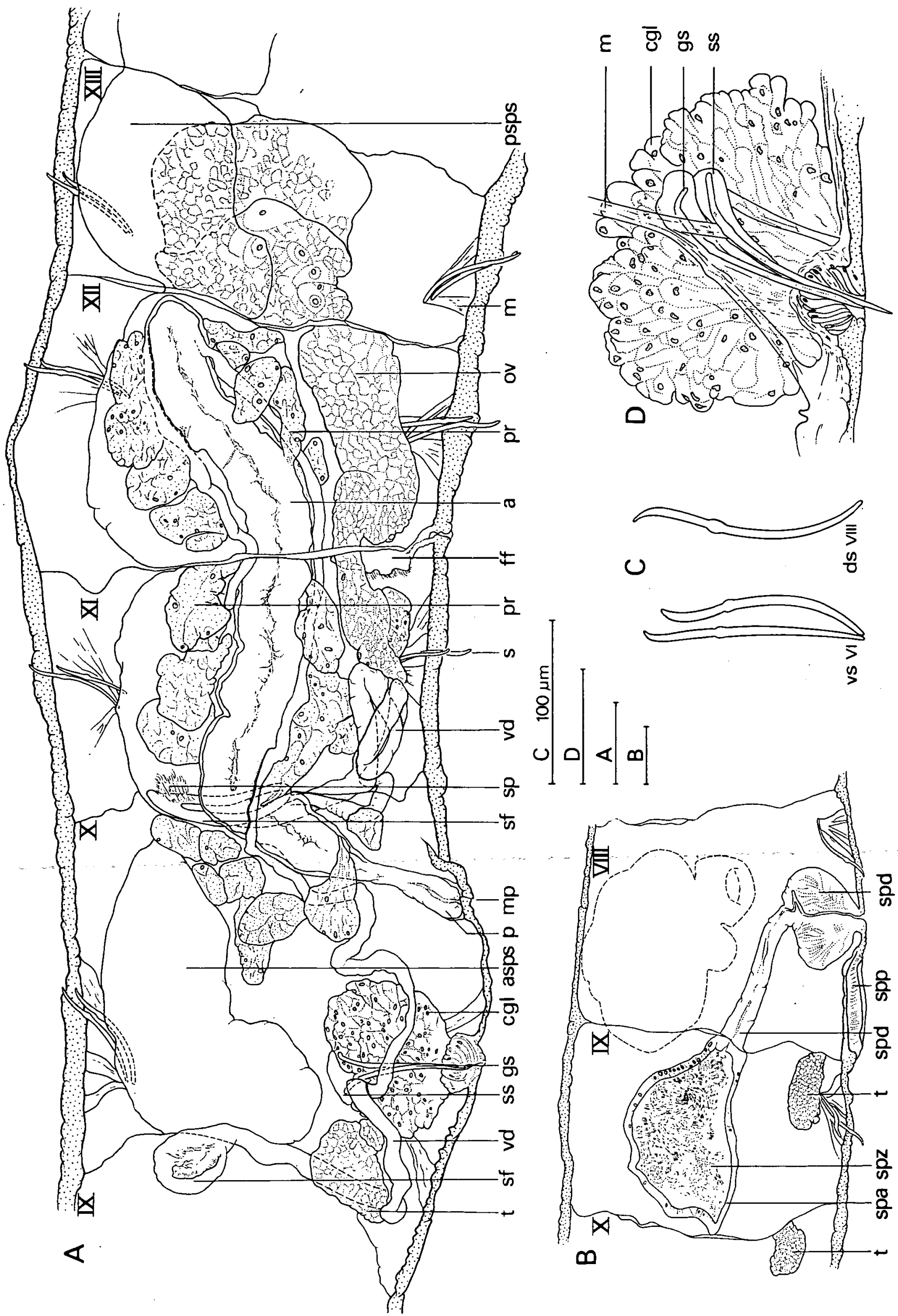

Fig. 1 : A-D.- Rhynchelmis alyonae sp. n. A.- Lateral view of genitalia in segments IX-XIII (holotype). B.- Lateral view of spermathecae (left spermathecal ampulla partly shown by dissection, part of right spermathecal ampulla remaining on the left side of the worm indicated by a dashed line; holotype). C.- Somatic setae (holotype). D.- Genital setae and copulatory gland in segment X (paratype 97.071.2).

Fig. 1 : A-D.- Rhynchelmis alyonae n. sp. A.- Vue latérale des génitalia dans les segments IX-XIII (holotype). B.- Vue latérale des spermathèques (l'ampoule spermathécale de gauche est montrée partiellement par la dissection, une partie de l'ampoule spermathécale de droite, laissée sur le côté gauche dù ver, est suggérée par une ligne discontinue; holotype). C.- Soies somatiques (holotype). D.- Soies génitales et glande copulatrice dans le segment $X$ (paratype 97.071.2). 


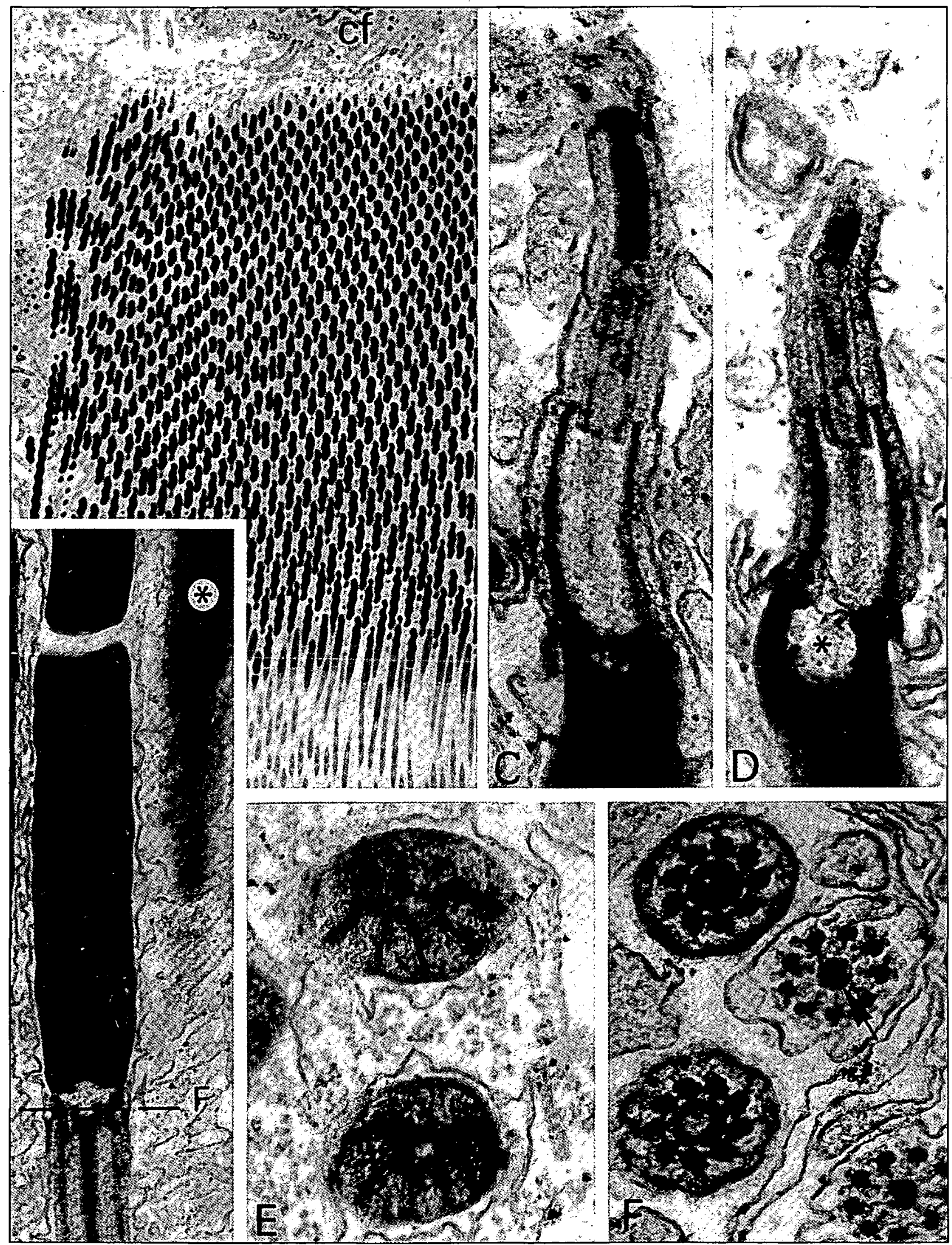

Fig. 2 : A-F.- Spermatozoa of Rhynchelmis alyonae sp. $\mathrm{n}$. at the ciliated funnel. A.- At low magnification (x 2,570), the spermatozoa appear highly ordered. At right, some of the nuclei are nearly longitudinally cut, and show the typical twisted-column shape. B.- Radial, longitudinal section of a midpiece (left) showing the mitochondria longitudinally cut and the basal body region of the flagellum. At right (asterisk) a tangential section of a midpiece shows the highly twisted arrangement of the mitochondria. A dotted line shows the level of the cross section in $F$ (x 42,000). C, D. - Two different acrosomes longitudinally cut show the details outlined in Fig. 3. An asterisk indicates the cavity on top of the nucleus in D. The cavity is not clearly visible in A, because the section is tangential (x 90,000). E. - Cross section of two midpieces: the six mitochondria are so twisted that only some of their profiles are clearly-cut: Note the canal at the midpiece center $(x 75,000)$. F.- Cross sections of the basal body and flagella. The two sections at left are cut at the level indicated by the dotted line in $\mathrm{B}$. The two profiles at right are flagella showing the typical «prominent central sheath» arrangement (arrow ; $x$ 75,000). 
The types of this species remain apparently in the private collection of L. N. Snimschikova (Limnological Institute of Irkutsk), and their access was once again denied to us, in complete contradiction with the requirements of the situation already occurred in the past for types of Lymphachaeta pinnigera Snimschikova, 1982; see Martin \& Brinkhurst 1998).

\section{Type locality.}

Lake Baikal, Maloye More, Olkhonskiye varota, Cape Umysh-Tame; 5300'25" N, 106 55'12"'); 17 June 1996; at 14-30 m depth (dredge); silty sand sediment.

\section{Paratypes.}

4 sexually mature specimens from the same station, dissected and mounted in the same way as the holotype; IRSNB slides 96.042.1, 96.049.1, 97.050.1; LISB slides 71.14.

\section{Other material.}

Type specimens of $P$. olchonensis Burov \& Kozhov, 1932 sensu Hrabè, 1982, NMPC P6j-20/89, slides Hr. 1724-5-H-II, Hr. 1724-5-H-II+w, Hr. 1724-5-H-III-IV, Hr. 1724-5-CH-I, Hr. 1724-5-CH-I-1, Hr. 1724-5-CHI-2, Hr. 1724-5-CH-II, Hr. 1724-5-J-I-2, Hr. 1724-5-JI-1, Hr.1724-5-J-IIw, Hr. 1724-5-IV, Hr. 1724-2-V, Hr.1724-2B-IVW,Vw,-VI.

\section{Etymology.}

The species is named after «Shaman», a sorcerer in the native Buryat people, who was assumed to have put a spell on Rhynchelmis genus because of the seemingly increasing puzzle of its systematics.

\section{Description.}

Small-sized species, $15.1 \mathrm{~mm}, 88$ segments, breadth $488-543 \mu \mathrm{m}$ at widest (clitellum). Prostomium rounded. Hardly discernible secondary annulation from III to VII, narrow annulus posterior, intersegmental annulation well-marked in postclitellar segments. Clitellum slightly noticeable, extending over $1 / 2$ IX - 1/2 XIII. Two single-pointed setae per bundle, sigmoid, with bent tips, similar in dorsal and ventral bundles, 77 $134 \mu \mathrm{m}$ long, $5.4-5.6 \mu \mathrm{m}$ thick, ectal nodulus on the upper third of seta (Fig. 4B). No modified genital setae. Setal length increasing from 77 to $134 \mu \mathrm{m}$ in VIII-
IX, slightly decreasing to a nearly constant length (100 $-102 \mu \mathrm{m}$ ) in postclitellar segments.

Dorsal pad of pharynx extending from II to III, pharyngeal glands in II-VIII. Two sperm sacs associated with each testis segment, backward pouchings of septa $9 / 10$ and $10 / 11$, confined in $X$ or extending to XIV, respectively (Fig. 4A, asps, psps). Egg sacs reaching XVII. One pair of spermathecal pores opening somewhat posterior to the middle of VIII, behind ventral setae and slightly medially from setal line. Long and tubular spermathecal ducts (Fig. 4A, spd), leading to voluminous ampullae roughly divided into two pouches of different sizes, a small proximal and a large distal one (Fig. 4A, spa). One ampulla usually filling the coelom in VIII, the other partially (large pouch) or totally pushed backwards in IX. Sperm as an amorphous mass in ampullae (Fig. 4A, sp). No communication between spermathecal ampullae and gut cavity.

Two pairs of testes in IX and X, attached ventrally to septa $8 / 9$ and $9 / 10$, respectively (Fig. 4A, $t$ ). Male pores paired, opening ventrally slightly medially from setal line and slightly before intersegmental furrow $\mathrm{X} / \mathrm{XI}$ (Fig. 4A, $m p$ ). Two pairs of sperm funnels, on septa $9 / 10$ and $10 / 11$, respectively, posterior funnels taller than anterior ones, both directed forward (Fig. $4 \mathrm{~A}, s f$ ). Vasa deferentia ciliated on entire length, 36 $\mu \mathrm{m}$ wide, narrowing to $19 \mu \mathrm{m}$ wide proximally to atrium, running parallel to atrium and entering near its apical end (Fig. 4A, vd). Anterior vas deferens running on the floor of $\mathrm{X}$, posterior vas deferens making some loops or going nearly straight down to XI, before coming back to $X$. Atria $560 \mu \mathrm{m}$ long, cylindrical, $54 \mu \mathrm{m}$ wide (Fig. 4A, a), terminated by small true penes in very shallow penial sacs (Fig. $4 \mathrm{~A}, p$ ), entering sperm sac and extending into XI, not far from back of XI. Atria surrounded ectally by small cells (Fig. 4A, cr) of different aspect than cells of prostatic glands. No rudimentary atrium. Prostate glands discrete, pear-shaped or elongate, covering atria and separately opening onto atrium by means of short duct (Fig. 4A, pr).

Female pores paired, nearly in line with ventral setae but sligthly dorsal. Ovaries paired, fixed ventrally to

Fig. 2 : A-F. Spermatozoïdes de Rhynchelmis alyonae $\mathrm{n}$. sp. au niveau du pavillon cilié. A. - A faible grossissement (x 2.570$)$, les spermatozoïdes apparaissent fortement ordonnés. A gauche, quelques noyaux sont coupés presque longitudinalement et sont typiquement en forme de colonne torsadée. B.- Coupe radiale, longitudinale d'une pièce médiane (à gauche) montrant les mitochondries coupées longitudinalement et la région du corps basal du flagelle. A droite (astérisque), une coupe tangentielle de la pièce médiane montre l'arrangement fortement torsadé des mitochondries. Une ligne discontinue montre le niveau de la section transversale en F (x 42.000). C, D.- Deux acrosomes différents, coupés longitudinalement, montrent les détails soulignés dans la Fig. 3. Un astérisque indique la cavité au sommet du noyau en D. La cavité n'est pas clairement visible en $C$ parce que la coupe est tangentielle (x 90.000). E.- Coupe transversale de deux pièces médianes : les six mitochondries sont tellement torsadées que seulement quelques-uns de leurs profils sont clairement coupés. Noter le canal au centre de la pièce médiane (x 75.000). F.- Coupes transversales du corps basal et du flagelle. Les deux coupes à gauches sont faites au niveau indiqué par la ligne discontinue illustrée en B. Les deux profils à droite sont des flagelles montrant l'arrangement typiquement en "gaine centrale saillante» (flèche; $x$ 75.000). 


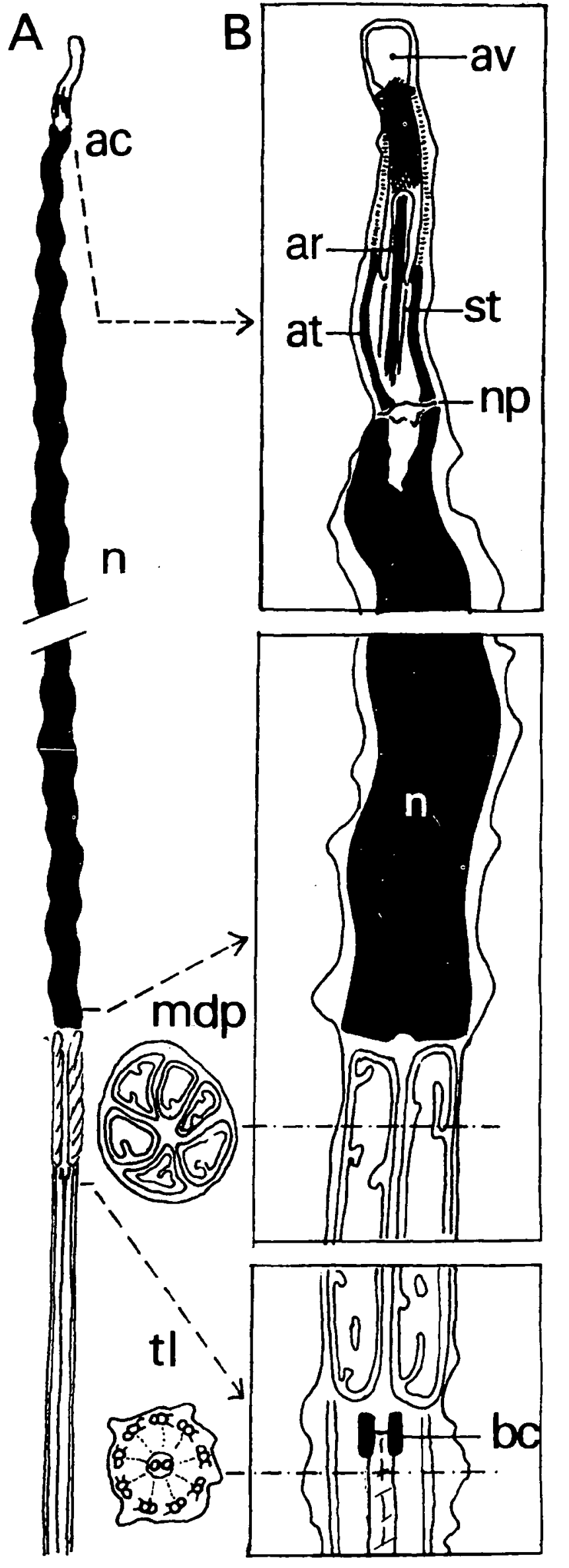

Fig. 3 : A-B.- Schematic drawings of a Rhynchelmis alyonae sp. $\mathrm{n}$. spermatozoon. A.- General view $( \pm x 11,000)$. B.- Details $( \pm x$ 55,000 ).

Fig. 3 : A-B.- Dessins schématiques d'un spermatozoïde de Rhynchelmis alyonae $\mathrm{n}$. $\mathrm{sp}$. A.- Vue générale $( \pm \mathrm{x} 11.000)$. B.Détails ( \pm x 55.000). septum 10/11 and extending to XII. Female funnels ciliated, attached to septum $11 / 12$, opening onto intersegmental furrow XI/XII (Fig. 4A, ff).

Ultrastructure of spermatozoa.

No material available.

Remarks.

Rhynchelmis shamanensis $\mathrm{sp} . \mathrm{n}$. belongs to this small group of Rhynchelmis that share the possession of two pairs of testes, two pairs of functional vasa deferentia, no connection between ampullae of spermatheca and gut cavity, no rudimentary atrium and longitudinal muscles not curled at their margins, namely $R$. alyonae sp. n., $R$. olchonensis and $R$. paraolchonensis.

The absence of copulatory glands allow an easy distinction of $R$. shamanensis sp. n. from $R$. alyonae sp. n. and $R$. olchonensis. As to $R$. alyonae, the other major differences are genital setae, modified spermathecal papillae and backwards extension of genital organs. Externally, $R$. shamanensis $\mathrm{sp}$. $\mathrm{n}$. mainly differs from $R$. paraolchonensis by the shape of setae (thinner and with an ectal tip straighter than in $R$. paraolchonensis; Fig. 5B, 2, 4), the number of segments ( 88 vs 125 $192)$, the size ( $15 \mathrm{~mm}$ vs $35-45 \mathrm{~mm})$ and the absence of small spermathecal vestibulae (Fig. 5C). Other significant differences are the size of atria $(480-646 \mu \mathrm{m}$ vs 286-380 $\mu \mathrm{m})$ and, interestingly, posterior vasa deferentia always directed towards anterior segments while they are directed towards posterior segments in $R . p a$ raolchonensis.

There are very few differences between $R$. shamanensis $\mathrm{sp} . \mathrm{n}$. and specimens of Rhynchelmis olchonensis Burov \& Kozhov, 1932 sensu Hrabè, 1982. Atria are called pear-shaped inHrabè's specimens but the definition of this character seems to be very subjective and its validity is queried since tubular atria were seen on whole-mounted specimens (paratype $\mathrm{Hr}$. 1724-5-HIII-IV; Fig. 5A, 3). Small differences are noticeable in atria's size (480-646 vs $307-432 \mu \mathrm{m}$ ), penes' size and extension of penial sacs (larger and deeper, respectively, on Hrabè's specimens) and in the presence of a cellular ring ectally surrounding atria in $R$. shamanensis $\mathrm{sp} . \mathrm{n}$. The latter character is difficult to distinguish from the cellular background, however, and its seeming absence on Hrabè's specimens is not conclusive. A similar structure was already illustrated (but not mentioned) in Rhynchelmis brooksi Holmquist, 1976 and is known in Stylodrilus glandulosus Giani \& Martinez-Ansemil, 1984) and in many Lamprodrilus species for which a glandular function is assumed. These differences are not deemed sufficient for justifying a specific distinction between the two taxa. Accordingly, 


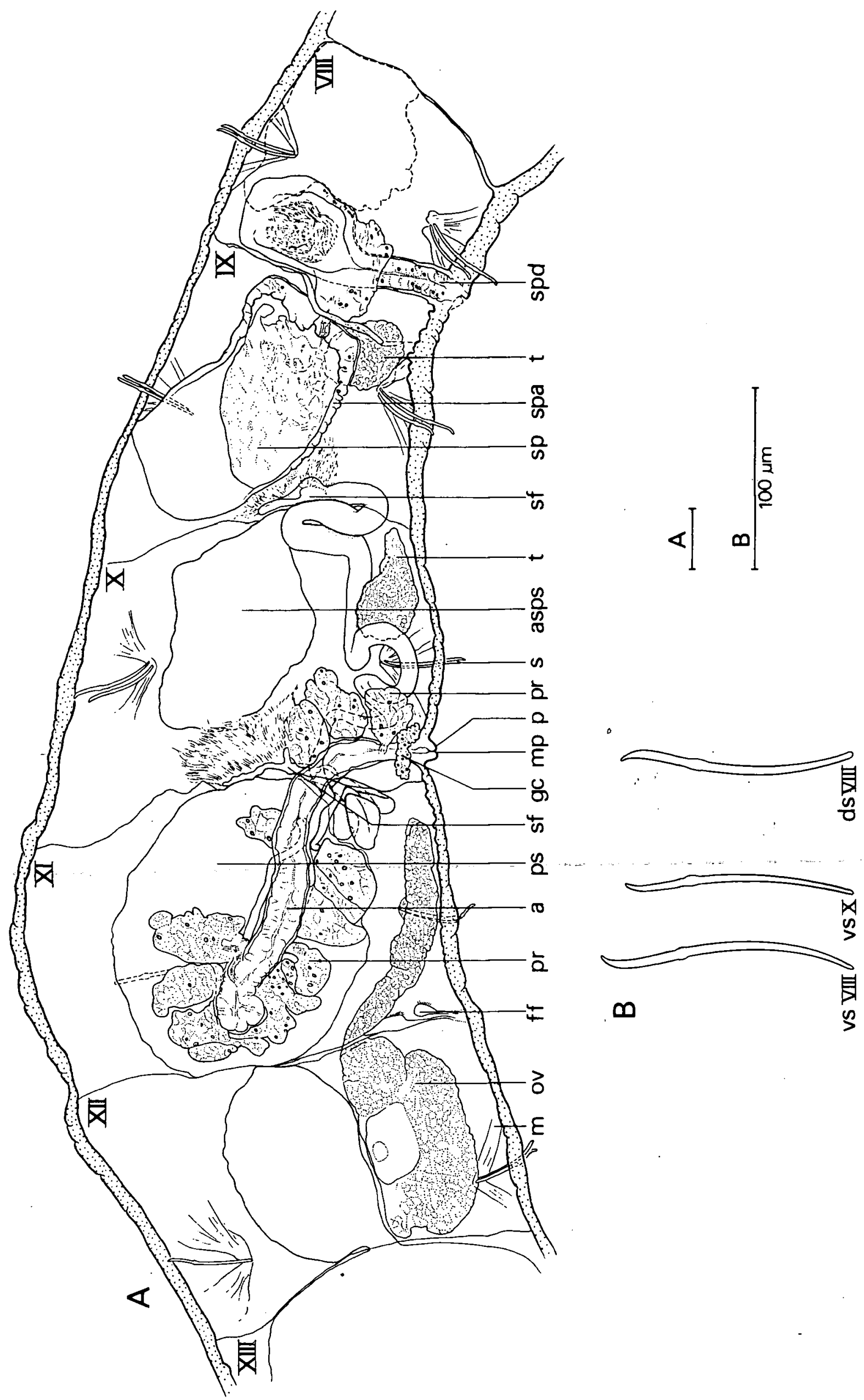

Fig. 4 : A-B.- Rhynchelmis shamanensis sp. n. A.- Lateral view of spermatheca and genitalia in segments VIII-XIII(holotype; right spermathecal ampulla left in segment VIII, on the left side of the worm suggested by a dashed line). B.- Somatic setae (holotype).

Fig. 4 : A-B.- Rhynchelmis shamanensis n. sp. A.- Vue latérale de la spermathèque et des génitalia dans les segments VIII-XIII (holotype; 1'ampoule spermathécale de droite, laissée sur la partie gauche du ver, dans le segment VIII, est suggérée par une ligne discontinue. B.- Soies somatiques (holotype). 


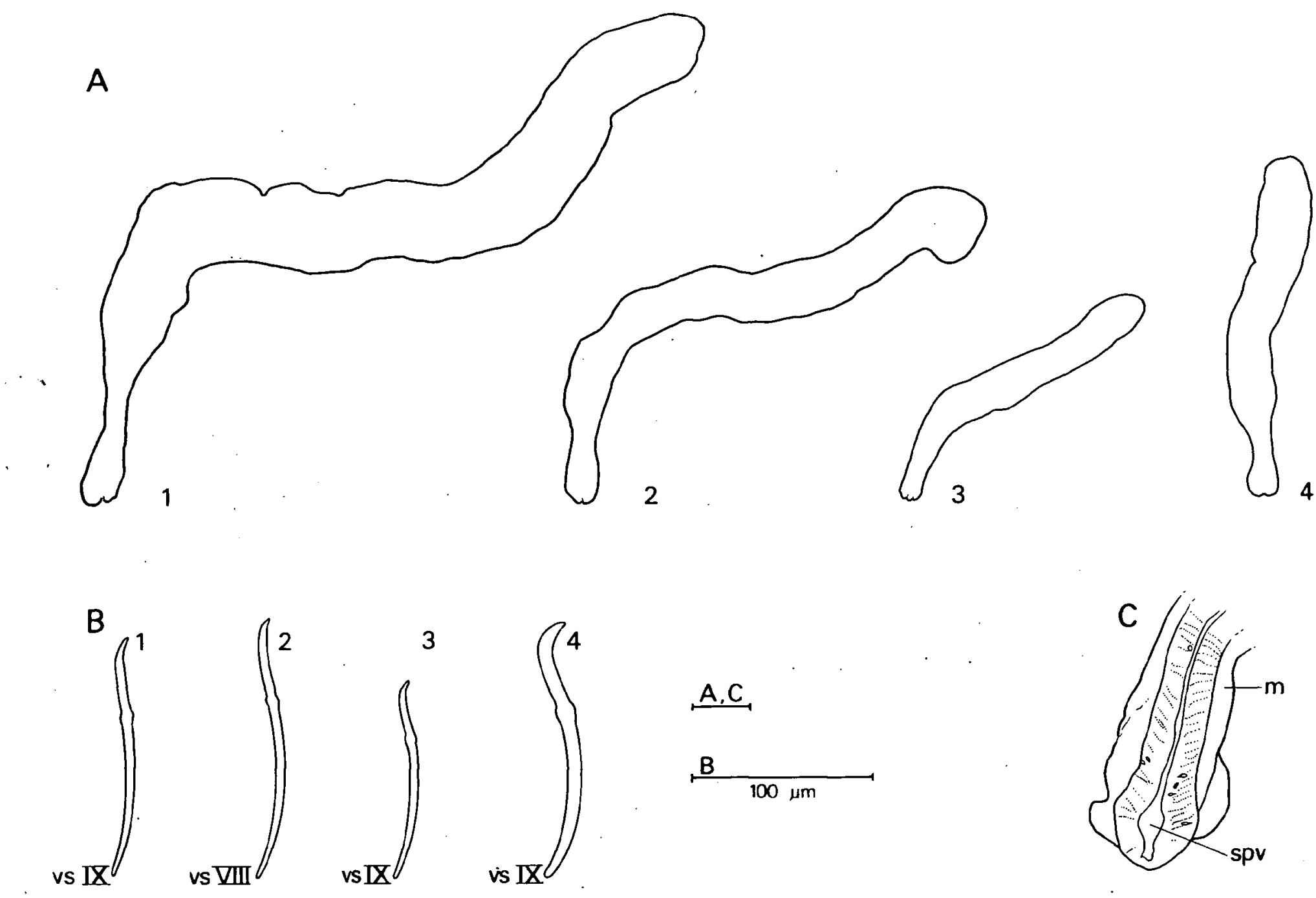

Fig. 5 : A-B.- Comparison between Rhynchelmis alyonae n. sp. (1), Rhynchelmis shamanensis n. sp. (2), Rhynchelmis olchonensis Burov \& Kozhov, 1932 sensu Hrabè, 1982 (3), and Rhynchelmis paraolchonensis (4). A.- Schematic drawing of respective atria. B.- Somatic setae. C.Ectal end of spermathecal duct in Rhynchelmis paraolchonensis.

Fig. 5 : A-B.- Comparaison entre Rhynchelmis alyonae n. sp. (1), Rhynchelmis shamanensis n. sp. (2), Rhynchelmis olchonensis Burov \& Kozhov, 1932 sensu Hrabè, 1982 (3), et Rhynchelmis paraolchonensis (4). A.- Dessin schématique des atria respectifs. B.- Soies somatiques. C.- extrémité ectale du canal spermathécal chez Rhynchelmis paraolchonensis.

we propose to consider Hrabe's specimens as Rhynchelmis shamanensis $\mathrm{sp} . \mathrm{n}$.

Geographical distribution and habitat.

To date, only known from Lake Baikal, Maloye More (Olkhonskiye varota, Cape Umysh-Tame, $30 \mathrm{~m}$, silty sand sediment).

\section{Discussion}

Amongst the 17 Rhynchelmis species known so far, $R$. alyonae sp. $\mathrm{n}$. and $R$. shamanensis $\mathrm{sp} . \mathrm{n}$. belong to this group of 6 species characterised by a lack of connection between spermathecal ampullae and gut cavity, namely : $R$. alaskana, $R$. orientalis, $R$. alyonae, $R$. olchonensis, $R$. paraolchonensis and $R$. shamanensis. The absence of the anterior pair of testes and of vas deferens (or the latter present but functionless) allows a separation between the former two (R. alaskana and $R$. orientalis) and all other species which have two pairs of testes and two pairs of functional vasa deferentia.
Hrabè (1982) defined the new genus Pseudorhynchelmis for $R$. olchonensis. Amongst the combination of characters used, only the length of posterior vas deferens seemed to be the exclusive characteristic of this species, which led Giani and Martinez-Ansemil (1984) to refute the validity of this taxon. The description of $R$. alyonae sp. $\mathrm{n}$. and $R$. shamanensis $\mathrm{sp}$. n. gives, however, more consistency to this taxonomical unit. It suggests that short, elongate and straight atria, not extending backwards further than segment XII, could be a unique apomorphy. Rhynchelmis brooksi Holmquist, 1976 has atria in X-XII / XIII but in this case, atria are coiled in such a way that they would largely extend further than segment XII if they were straight elongate. However, it is preferable not to take the decision of revalidating the genus Pseudorhynchelmis, and to await the results of a cladistic analysis of Rhynchelmis in progress elsewhere (Fend, pers. com.).

Interestingly, the validity of this taxonomical unit is indirectly supported by the comparison between ultra- 
structure of spermatozoa of $R$. alyonae sp. n. and $R$. brachycephala and $R$. limosella. The two latter species have long atria, extending through many segments (to XVII in R. brachycephala) and one unpaired, so-called «rudimentary atrium» in IX. Such differences are remarkable in species supposed to belong to the same genus.

As other representatives of this group, Rhynchelmis spermatochaeta Semernoy, 1982 has two pairs of testes, two functional vasa deferentia, and short atria, not extending backwards further than segment XI, but it is supposed to have a connection with the spermathecae and the gut cavity. A rapid examination of type specimens did not enable us to see such a communication and the validity of this character is queried.

Other species are very likely to be added to this group. Indeed, an examination of Rhynchelmis specimens of Lake Baikal from the Semernoy's collection strongly suggested the existence of new species, with short atria, genital setae and/or copulatory glands, still undescribed to date. The Baikalian Rhynchelmis representatives of this group appear more and more as a species flock within the lake, constituted, by definition, of neoendemics (Martin 1996). Amongst the group, $R$. paraolchonensis is the only non-Baikalian species. It is therefore tantalizing to consider it as the closest to the species that colonized the lake and was at the origin of this flock.

Such a hypothesis has the advantage subsequently allowing a polarization of characters. This would mean that (1) if a short atrium (not extending beyond segment XI) is a synapomorphy in the group, the elongate atrium of $R$. alyonae (extending into XII) is not homologous with the one of $R$. brooksi (atrium in X$\mathrm{XII} / \mathrm{XIII})$, (2) posterior sperm funnels directed towards anterior segments is the plesiomorphic character within the group, (3) the copulatory glands are a synapomorphy in $R$. alyonae and $R$. olchonensis, and (4) genital setae are an autapomorphy in $R$. alyonae.

Modified genital setae were also described in Thinodrilus genitosetosus by Holmquist (1976). At that time, this character was unique in the family Lumbriculidae. Since then, «spermathecal setae» were mentioned by Semernoy (1982) in Rhynchelmis spermatochaeta, differing only from other setae by a greater size, which left a doubt about the validity of this distinction. The present description of genuine genital setae in $R$. alyonae sp. $n$. confirms that this character can independently arise amongst members of this family. A future study of Baikalian Rhynchelmis should reveal other species with genital setae.

\section{Acknowledgments}

We are especially grateful to Michael Grachev, Director of the Limnological Institute of Irkutsk, for supporting foreign research on Lake Baikal. We are indebted to the captain and the crew of the R/V Vereschagin for their assistance during the fieldwork. We also express our gratitude to Steven V. Fend (USGS, USA) for his very useful comments, Narcisse Giani (Université de Toulouse, France) for placing types of Rhynchelmis paraolchonensis at our disposal, to Antonín Kürka (National Museum of Prague, Department of Zoology, Vàclavské námèstí 68, CS-115 79 Praha 1) for sending us Hrabè's types on loan, and to Victor P. Semernoy (University of Yaroslavl, Russia) for sharing with us unpublished data and sending us some Rhynchelmis material from his collection. We thank Claudine Devries-Duchène for kindly making a neat copy of the figures. This work was organised under the auspices of BICER (Baikal International Center for Ecological Research) and with the financial support from the Belgian Ministry of National Scientific Institutions, the Siberian Branch of the Academy of Sciences of Russia, and INTAS (International Association for the Promotion of Cooperation with Scientists from the Independent States of the former Soviet Union; project INTAS-94-4465).

\section{References}

Burov V. \& Kozhov M. 1932. - K raspredeleniyu donnoi fauny v Malom more na Baikale (= Distribution of benthic fauna in the Maloye More near Baikal). Tr. Vost.-Sibirsk. Gos. Univ., 1: 60-85. [In Russian with German summary].

Ferraguti M., 1984. - The comparative ultrastructure of sperm flagella central sheath in Clitellata reveals a new autapomorphy of the group. Zool. Scripta,13: 201-207.

Ferraguti M., 1998. - Euclitellata. In : Jamieson, B. G. M. (ed), Reproductive Biology of the Invertebrates, Progress in Male Gamete Biology, in press.

Ferraguti M., Erséus C., Kaygorodova I. \& Martin P. 1998. - New sperm types in Naididae and Lumbriculidae (Annelida: Oligochaeta) and their possible phylogenetic implications. Hydrobiologia, in press.

Giani N. \& Martinez-Ansemil E. 1984. - Deux nouvelles espèces de Lumbriculidae du Sud-Ouest de l'Europe. Annls Limnol., 20 : 157-165.

Holmquist Ch. 1976. - Lumbriculids (Oligochaeta) of Northern Alaska and Northwestern Canada. Zool. Jb. Syst., 103: 377-431.

Hrabè S. 1982. - Contribution to the knowledge of Oligochaeta from the lake Baikal. Vest. cs. Spolec. zool., 46: 174-193.

Kozhov M. 1963. - Lake Baikal and its life. The Hague (The Netherlands), Dr. W. Junk, 344 pp.

Martin P. 1994. - Lake Baikal. In : K. Martens, B. Goddeeris \& G. Coulter (eds), Speciation in Ancient Lakes, Arch. Hydrobiol. Beih. Ergebn. Limnol., 44 : 3-11.

Martin P., 1996.- Oligochaeta and Aphanoneura in ancient lakes : a review. Hydrobiologia, $334: 63-72$.

Martin P. \& Brinkhurst R. O. 1998. - A new genus and two new species of Tubificidae (Oligochaeta) from the abyssal zone of Lake Baikal with redescriptions of Lymphachaeta pinnigera, Rhyacodriloides abyssalis and Tubifex bazikalovae. Zool. Scripta, in press.

Semernoy V. P. 1982. - Novye vidy oligokhet iz ozera Baikal (= New oligochaete species from Lake Baikal). In : G. I. Galazii (ed), Novoe of faune Baikala (= New Information on the Fauna of Lake Baikal), Novosibirsk, USSR, Izdatelstvo Nauka, Sibirskoe otdelenie (=Science Press, Siberian Branch) : 58-85.

Snimschikova L. N. \& Akinshina T. W. 1994. - Oligochaete fauna of Lake Baikal. Hydrobiologia, 278 : 27-34. 